\title{
Study of hemolytic activity and subfactors of complement in smokers intoxication
}

Rojan Ghanim Al Allaf ( $\square$ rojan6791@yahoo.com )

University of Mosul Mosul, Nineveh IRAQ

Research article

Keywords: $\mathrm{C} 3, \mathrm{C} 4, \mathrm{CH} 50 \%$, Heavy smoke, Inverse equation

Posted Date: September 3rd, 2019

DOI: https://doi.org/10.21203/rs.2.10950/v1

License: (c) (i) This work is licensed under a Creative Commons Attribution 4.0 International License. Read Full License 


\section{Abstract}

Heavy Smokers appeared to be less resistant to infection, such as bacteria, viruses, and parasites. Many studies have examined the complement components concentrations than compared with normal people and ignored the functional sequencing of complement components, our study included the determination of complement activity by using Sheep red blood cells (SRBCs) as antigen and extracting the hemolytic activity (50\%) of complement compounds, and because of difficulty of this method we using statistical analysis program (SPSS 23) and derived the inverse equation which gives the decomposition percentage (1-100\%) of complement components by using five serum dilutions only. The total hemolytic complement activity ( $\mathrm{CH} 50)$ and its $\mathrm{C} 3$ and $\mathrm{C} 4$ fractions were determined in 30 heavy smokers. The results were compared with a control group that contained 30 persons matched in age and sex. Generally, both C3 and C4 concentrations were increased in smoker's individual in compared with the control group. However, when the independent t-test has applied the differences in the C3 and C4 levels in the control group (healthy individuals) and in the smoker group were found to be statistically insignificant but the inverse equation showed a $7 \%$ reduction in $\mathrm{CH} 50$ in smokers compared with the control group, where $18 \%$ reduction was observed. Our current study suggests that the complement components of the heavy smokers suffer from a significant dysfunction in the function, although the concentration of the basic components in the serum is parallel with normal values.

\section{Background}

Cigarette smoke (CS) is an emergent cause of mortality that can be eliminated by prevention [1]. Gross global, more than 3 million people suffered from serious diseases that cause death in smoking persons each year [2]. The mortality ration of death in smoking peoples were dependent on many factors; in which the daily average consuming number of cigarettes, the time of cigarette consumption, the depth of inhalation and the age were the smokers start smoking cigarettes, these factors are the most important risk factors that increase death numbers [3,4]. The smoke of cigarette contains more than 4000 different chemical compounds, a potentially carcinogenic compound in this smoke were more than 400 chemicals; in addition to oxidants that cause damages to biomolecules such as oxygen free radicals and volatile aldehydes [5]. Cigarette smoke contains chemical substances with high cytotoxic potentials [6]. Nicotine and tar considered as carcinogenic chemicals in addition to the gaseous form of carbon monoxide [7]. Oxidative injury was initiate and promote by free radicals that found in large quantities in cigarette smoke [8].

Long (chronic) inhalation of cigarette cause massive alteration in immune system response, especially in innate and adaptive immunological functions. Several recent scientific reports have indicated that most of the health problems caused by chronic consumption of cigarette smoke can be attributed to dysfunction of the immune system. Many medical reports dating back to the 1960s suggest that an increase in smoking-related diseases can be caused by tobacco, which changes the response of the immune system and inflammatory reaction [9]. Cigarette smoking changes many immune system functions in both human and laboratory animals, and these changes can be observed in both cellular and 
humoral immune responses, numerous medical reports have suggested that impair the immune system may be attributed to increased exposure to cigarette smoke [10].

The complement system is an essential element of the immune system especially innate part, which is responsible for defense against bacterial invasion, in addition to its share part in removing immune complexes and dead cells. Both complement 3 and 4 are the most important proteins in blood plasma, which mostly interferes in immune response mediated by complement pathways. During inflammatory response due to infections, synthesis of $\mathrm{C} 3$ and $\mathrm{C} 4$ increases, but these increase in production is lower than recorded when compared with conventional acute phase proteins [11].

The inhalation of cigarette smoke is supposed to activate the complement system, which is it initiates production of cytokines that cause attraction of leukocytes in the pulmonary fluid [12].

A number of studies have examined the total hemolytic activity of complement and chose to study the effect of smoke on purified C3 [12]. Other studies have recently demonstrated the consumption of complement hemolytic activity in serum following its incubation with cigarette smoke condensate $[13,14]$.

Very few studies have examined complement hemolytic activity $\mathrm{CH} 50$ in smokers, possibly because of the difficulty in determining it. Therefore, our current study investigates the concentration of the complement 3 and complement 4, and measured complement hemolytic activity $\mathrm{CH} 50$ with sensitized sheep red blood cells.

\section{Methods}

60 persons were included in the current study, which divided into two groups. Group1 included 30 heavy smokers, aged between 20-45 years. In this group, the mean number of cigarettes smoked per day was 30-40, and the group members had been active smokers for a period of at least 5 years from the study's commencement date. All smokers were apparently healthy and demonstrated no clinical symptoms, while 4 smokers suffered from trouble breathing, shortness of breath and coughing. Individuals diagnosed with viral infection or autoimmune disease were not included in experiment groups. Group 2 consisted of age- and sex-matched non-smokers individual with no signs of illness or symptoms of autoimmune disease.

\section{Sample collection:}

Blood samples were obtained via venipuncture. Blood samples collected from the participants were allowed to clot at room temperature for $30 \mathrm{~min}$. later the samples of collected serum were separated from blood by centrifugation for 15 minutes at speed $2500 \mathrm{rpm}$. A serum sample was collected and preserved in the deep refrigerator at $-70 \mathrm{C}^{\circ}$.

\section{Complement 3 and complement 4 identification:}


Both complements ( 3 and 4) were calculated by a protocol described by Mancini et al, 1965 using an immunodiffusion technique kit supplied by LTA Company [15]. The blood serum was poured into the wells then incubated for 48 to 72 hours. A precipitation diameter of each serum sample was calculated and the protein concentration was recorded from the table supplied with the kit and termed as Reference Table. The normal value of C3 is ranged between 91 and $156 \mathrm{mg} / \mathrm{dl}$ and for C4 it is ranged between 20 and $50 \mathrm{mg} / \mathrm{dl}$.

\section{Measuring the $50 \%$ Hemolytic Complement (CH50) Activity of Serum}

In order to measure the $50 \%$ Hemolytic Complement (CH50) activity of serum, a number of preliminary steps were taken. These included:

\section{Preparation of 5x Veronal Buffered Saline (VBS)}

To prepare the veronal buffered saline solution, a three solution should be prepared in advanced then they mixed in specifically arranged to obtain VBS as follow:

Solution I: it was prepared from dissolving 21.25 grams of Sodium Chloride with 0.94 gram of Sodium Barbiton in $350 \mathrm{ml}$ of distilled water (1.02M for Sodium Chloride, $13 \mathrm{mM}$ for Sodium Barbiton in prepared solution).

Solution II: it was prepared from dissolving 1.44 gram of Barbiton in $125 \mathrm{ml}$ of hot distilled water (62.5 $\mathrm{mM}$ of the prepared solution).

Solution III: it was prepared from dissolving of 4.41 grams of Calcium Chloride and 20.33 grams of Magnesium Chloride in $100 \mathrm{ml}$ of distilled water $(440 \mathrm{mM}$ for Calcium Chloride, $2.18 \mathrm{M}$ for Magnesium Chloride in prepared solution).

Mixing Steps: At the first step, the solution I and Solution II were mixed at prepared volume and allowed to cool at room temperature (since the solution II is prepared in hot distilled water). Later, add $1.25 \mathrm{ml}$ of Solution III and bring the $\mathrm{pH}$ to $7.3-7.5$ by using $\mathrm{HCl}(1 \mathrm{M})$. After adjusting the $\mathrm{pH}$ the volume of final solution should be fixed at $500 \mathrm{ml}$ using distilled water, in order to prepare $5 \mathrm{x}$ of stock solution of VBS, which should be preserved in the refrigerator till it used and marked as Stock Solution. In order to prepare the working solution of VBS, the stock solution which is previously prepared were diluted at 1:5 with distilled water.

\section{Sensitization of sheep red blood cells with hemolysin}

Hemolysin (rabbit anti-sheep red blood cell antibody) was prepared by diluting at 1:50 with VBS. $6 \mathrm{ml}$ of VBS was added to $4 \mathrm{ml}$ of sheep red blood cells (SRBC) and mixed gently by inversion. The resulting 
mixture was centrifuged at $600 \mathrm{~g}$ for $5 \mathrm{~min}$ and the supernatant discarded. The cell pellets were washed twice again with a mixture of VBS and SRBC. Later, the pellets were centrifuged at $900 \mathrm{~g}$ for $5 \mathrm{~min}$ to collect cells, the supernatant was discarded. Cells resuspended by VBS to prepare a $10 \%$ solution, in which $1 \mathrm{ml}$ of collected cells were resuspended in $10 \mathrm{ml}$ of VBS. Later, an equal volume of hemolysin was added to collect cells from the previous step with continuous swirling. The mixture was incubated at $30^{\circ} \mathrm{C}$ for 30 minutes in a water bath while being mixed every $15 \mathrm{~min}$. The final solution of SRBC (sensitized) was stored in a refrigerator overnight.

\section{$\mathrm{CH} 50 \%$ assay}

Clean glass tubes were labeled 1:8, 1:16, 1:32, 1:64 and 1:128 in duplicate. Next two-fold dilutions in serial manure were performed at the serum of test and control group in VBS were prepared in each duplicate for each label. Beginning with the 1:4 (100 $\mu$ l serum with $300 \mu \mathrm{l}$ VBS) tube, $200 \mu \mathrm{l}$ of the sample was transferred into the next tube. After mixing, another transfer of $200 \mu \mathrm{l}$ was made to the next tube were done using a new pipette tip. This was repeated until the final dilution (1:128) were prepared. A 200 $\mu \mathrm{l}$ aliquot of suspended sensitized SRBC was added to all tubes. Also, $200 \mu \mathrm{l}$ of sensitized SRBC with 200 $\mu$ V VBS was added to two separate tubes labeled as 'blank'. Another two tubes containing $200 \mu \mathrm{l}$ of sensitized SRBC with $200 \mu \mathrm{l}$ distilled water were labeled as 'total lysis'. The tubes were gently mixed every 15 minutes while incubating at $37^{\circ} \mathrm{C}$ for 30 minutes in a water bath. Following the incubation period, the resulting mixture was centrifuged at $1,500 \mathrm{~g}$ for $5 \mathrm{~min}$ to sediment the RBC. Then $100 \mu \mathrm{l}$ of supernatant from each tube were added to each well. A $100 \mu$ of distilled water was added to each well. The well result was read using plate spectrophotometer reader at $540 \mathrm{~nm}$ wavelength.

\section{Data analysis}

The mean absorbance was calculated for each sample after subtracting the BLANK absorbance (spontaneous lysis) from the absorbance recorded for all samples. The percentage lysis was estimated for each dilution using the formula:

Due to technical limitations, Equation 1 has been placed in the Supplementary Files section.

Plots of the percentage lysis (vertical axis) versus the serum dilution on the horizontal axis were created as described in a previous study [16]. The data were analyzed using an independent-sample t-test to check whether there were statistically significant differences at $p \leq 0.05$. An inverse equation was applied to extract the $50 \%$ hemolytic activity value. All statistical analysis was performed using SPSS version 23 .

\section{Results}


The result of data analyses showed that the concentration of complement 3 and 4 were higher among smokers compared to the control group (Table 1). For instance, the minimum C3 concentration was $183.73 \mathrm{mg} / \mathrm{dl}$ for the smoker group while it was $146.24 \mathrm{mg} / \mathrm{dl}$ for the control group. A similar observation was observed for C4 (Table 1). However, when the independent t-test was applied to the mean concentration of $\mathrm{C} 3$ and $\mathrm{C} 4$ levels in the control and smoker groups were found to be statistically insignificant (Table 1).

The result also showed a significant decrease in the hemolytic activity of complement in all dilutions $1 / 8,1 / 16,1 / 32,1 / 64$ and 1/128 compared with control, as shown in table (2).

Estimation of the percentage of hemolytic activity $(\mathrm{CH} 50)$ of the complement components using a dilution is typically very difficult to manually determine. Hence, in this study, we used the inverse equation in the SPSS23 program to determine the value of hemolysis at $50 \%$. In addition, the inverse equation provides an opportunity to extract the value of hemolysis at any level of hemolysis chosen by the researcher $(1-100 \%)$. The equation is based on a reconciliation between the dependent variable, which is the percentage of the decomposition of the SRBC by a complement of smokers and the independent variable that is the effect of the dilution. The inverse equation is given as:

Due to technical limitations, Equation 2 has been placed in the Supplementary Files section.

$\mathrm{Y}$ represents the value of decomposition of red blood cells by the complement and $\mathrm{X}$ represents both serum vasoconstriction and control sample. The inverse equation showed a 7\% reduction in $\mathrm{CH} 50$ in smokers (Table $3 \mathrm{a}$ ) compared with the control group, where an $18 \%$ reduction was observed (Table $3 \mathrm{~b}$ and Fig. 1).

\section{Discussion}

The result of data analyses showed that the concentration of complement 3 and 4 were higher among smokers compared to the control group (Table 1). For instance, the minimum C3 concentration was $183.73 \mathrm{mg} / \mathrm{dl}$ for the smoker group while it was $146.24 \mathrm{mg} / \mathrm{dl}$ for the control group. A similar observation was observed for C4 (Table 1). However, when the independent t-test was applied to the mean concentration of $\mathrm{C} 3$ and $\mathrm{C} 4$ levels in the control and smoker groups were found to be statistically insignificant (Table 1). Our results disagree with the previous study. For instance, [12] showed that cigarette smoke contains numerous compounds especially methylamine, which causes break down the thioester bonds in C3 leading to alternative pathway activation, this alternative pathway mechanism may explain the increase in the level of C3 in all smokers. Our study agrees with the study by [17], which they found the mean serum levels of C3 and C4 statistically insignificant compared with control. 
Some of the subjects in our study suffered from wheezing and shortness of breath. The increased levels of $\mathrm{C} 3$ in some smokers may be associated with allergic and inflammatory reactions caused by smoke that contains a huge number of harmful compounds.

Activation of complement factors may be an important part of inflammatory processes. Smoke does not activate $\mathrm{C} 1$, indicating that it does not activate the classical pathway. However, smoke completely consumes serum $\mathrm{C} 4$. Since $\mathrm{C} 4$, like $\mathrm{C} 3$, contains an internal bond [18], cigarette smoke may directly consume $\mathrm{C} 4$ by cleaving its thioester without activating the classical pathway. This may explain the change in $\mathrm{C} 4$ concentration in some of the smokers in this study.

Depending on the collected data, the results exclude the effect of complement 3 and/ or complement 4 in developing the pathogenesis of inflammation induced by smoking cigarettes. Instead, a traditional protocol known as total hemolytic assay ( $\mathrm{CH} 50$ ) were used in this study to determine the function of complement activity. In short definition, $\mathrm{CH} 50$ calculate the ability of test serum to lyse half of the standard solution of sheep red blood cells coated with anti-erythrocyte antibody (terminal complement components and classic activation were calculated). In which, total complement activity indicated abnormal value if any component were defective [19].

The $\mathrm{CH} 50$ test will determine the ability of serum to hemolysis the sheep red blood cells, this test is always used for assessment the classical activation pathway of the complement system at the first step. The result of $\mathrm{CH} 50$ test will report the level of dilution of serum that can induce hemolysis of $50 \%$ of sheep red blood cells. Any increase in $\mathrm{CH} 50$ test results indicates an increase in activity of classical activation pathway for complement system, these increase in activity of complement system activation were not associated with any clinical signs except it probably indicate a process of active inflammatory and immune response. In other hands, undetectable $\mathrm{CH} 50$ test result indicates that a complement system suffering from a deficiency in any component of its elements. So, any defect in the production of any elements of the complement system will lead to dysfunction in classical activation pathways of complement.

The Inherited dysfunctions present in may clinical features included recurrent infection and autoimmune disorders. The recurrent infection can relate to respiratory system inflammation (as in sinusitis, bronchitis, and pneumonia), meningitis and sepsis. Streptococcus pneumonia considers the most common bacterial causes of these previous cases [20].

Autoimmune disorder and recurrent bacterial infection can associate with deficiencies in elements of complements $1,2,3$, and 4 . In the other hand, the deficiency in complement 2 components did not associate with and clinical illness in individuals, while a deficiency in complement 3 components mostly associated with severe recurrent infection, and autoimmune disorders. The components of complement 5 to complement $\mathrm{C} 9$ form the membrane attack complex (MAC) that leads to direct destruction of antigen [19]. 
The complement system may be playing an important role as a central responder of the immune system which can affect the production of immunoglobulins [21]. CH50 test result depends on all the classical components, so any changes in the concentration of any of the components will lead to changes in the total activity of the complement system. Hemolytic activity of complement can be affected when there are considerable changes in the concentration of any of the components [22].

One notable cause of the reduction in $\mathrm{CH} 50$ is the presence of underlying hepatic disease [23] since the liver is responsible for producing most of the complement components. Cigarette smoke causes a wide range of harmful effects on organs that are not related to direct association with smoke, as in the liver. The heavy smoking individual will introduce toxins to their circulation, that lead to necroinflammation result in increased in the severity of the lesions occurs in hepatic parenchyma [24].

Cigarette smoke can cause harmful changes on the liver and its function which included in three categories (1) toxic changes [25], (2) immunological changes [26] and (3) oncogenic changes [27].

A previous study [28] indicated that compounds in cigarette smoke can cause complement alternative pathway activation through specific modifying in $\mathrm{C} 3$ chemical bounds. This suggests that the alternative pathway works more than the classical pathway, which is dependent on antibody-antigen reaction, despite the increased level of immunoglobulins in smokers [29]. However, the classical pathway seemed to be not so active in smokers compared with the control group. Cigarette smoke contains numerous oxidants, which produce free radicals that affect neutrophils and generate oxidative stress in the body. This, in turn, produces highly reactive oxygen and nitrogen species [29].

Complement activation begins with a series of enzymatic reactions with $\mathrm{C} 1 \mathrm{q}$ until it reaches the $\mathrm{C} 5$ component. The proteolytic activity begins when it reaches the $\mathrm{C} 9$ component. Oxidative stress directly exerts its effects on enzymatic reactions and reduces the hemolytic activity of the classical complement pathway. In addition, other studies have recently demonstrated the consumption of complement hemolytic activity in serum following its incubation with cigarette smoke condensate [13].

Some studies that examined the total hemolytic activity of complement chose to study the effect of smoke of cigarettes on purified complement 3 , this related to two main facts which are (1) high concentration of this complement in blood serum, also (2) C3 consider as a key master to activate classical and alternative pathways [12]. Despite the high concentration of C3 in 10 smokers in the current study, the rate of hemolytic activity was still lower than in the control group, indicating a decrease in activation of the classical pathway. In contrast, we also observed lower and normal levels of C3 in other smokers. The decline in $\mathrm{CH} 50$ was possible because the classical pathway needs a high level of $\mathrm{C} 3$ component in serum for its activation.

\section{Conclusions}

By following these studies and comparing the results within our current study we conclude that there is a defect in the function of the complement system and the emergence of indicators of the inflammatory 
state, although all smokers do not show any disease or inflammatory stats, but the presence of the reduction in $\mathrm{CH} 50 \%$ is a clear indication of the presence of inflammatory condition may be attributed to an increase in antioxidants, which it may leads to a defect on the genes which is leads to appearance of a new strange antigenic proteins on the body and begin autoimmune disorder, or a defect in the functions of liver and lung on smokers, especially because they are exposed to inhalation of a large number of toxic substances, which enter to tissue and interact with it, or the complement protein associated with toxic oxides that enter the body through smoking and lead to the occurrence of synthetic changes in it and thus invalidate it works, or at least reduce the immune response as shown in the results of our research

\section{Declarations}

Abbreviations: SRBCs: Sheep Red Blood Cells, CH50: Complement Hemolytic (50\%), C: complement compounds, VBS: Veronal Buffered Saline, MAC: Membrane attack complex

Ethics approval and consent to participate: This study was approved by Scientific Committee in the Department of Biology, Science collage, University of Mosul, and carried out according to Institutional guidelines, all participants provided written consent.

Consent for publication: Not applicable

Availability of data and material: The datasets generated during the current study are available from the corresponding author on reasonable request.

Competing interests: The author declare that there are no competing interests.

Funding: Not applicable

Authors' contributions: Not applicable

Acknowledgements: The author would like to thank all patients for their participation, And also would like to thank Mohamed A. Al-Shahery and Khayri Bdl Rashid for facilitate the realization of this work. 
Authors' information: Biology Dep., Science collage, Mosul University

\section{References}

1. Wang TW,Asman K, Cullen,KA,Holder-Hayes E,Guzman CR.Tobacco Product Use Among Adults United States.Morbidity and Mortality weekly Report.2018;67(44)1225-32.

2. World Health Organization .WHO Report on Global Tobacco Epidemic .2017 Genera ,world health organization.(accessed 2019 Jan 31).

3. Jha P,Ramasundavahettigem C,Landsman V,Rostrom B,Thun M,Anderson , RN et al $.21^{\text {st }}$ Century Hazards of Smoking and Benefitsof Cessation in United States.New England $\mathrm{J}$ of Med.2013;368(4);341-50.

4. Lubin JH, Alavanja MC, CaporasoN, Brown LM, Brownson RC, Field RW. Cigarette smoking and cancer risk: modeling total exposure and intensity. Am J Epidemiol. $2007 ; 166: 479-89$.

5. McRobbie H,Phillips A,Goniewicz ML,Myers Smith KmKnight-West Om et al .Effects of Switching to electronic Cigarettes with and with out Concurrent Smoking on Exposure to Nicotine Carbon Monooxide and acrolein.Cancer Prev Res.2015;8:873-8.

6. Paumgartten FJ,Gomes-Carneiro MR,Oliveira AC.The impact of Tobocco Additives on cigarette smoke toxicity:a critical appraisal of tobacco industry studies.cadSaude Publica .2017;(33)Sup3540559.

7. Jabbar DK and Abdul-Hassan.Cigarette Smoking and Serum Liver Enzymes.J of Babylon University/ pure and applied Sciences.2017; 3(25)1111-1117.

8. Qiu FM;Fan P;Nie GD;Liu H;Liang CL;Yu Wm et al .Effects of Cigarette Smoking on Transplant Survival :Extending or Shortening.Front.Immunol.10 Feb 2017;8:127 doi:10.3389/fimmu 2017.00127.

9. Qiu FM,Liang CL;Liu H;Zang YQ ,Hou S,Huang S. et al .Impacts of Cigarette Smoking on Immune responsiveness:Up and down or up side down.oncotarget.3 Jan 2017;8(1)268-284.

10. Lubin J H, Couper D, Lutsey PL, Woodward M, Yatsuya H, and Huxley Risk of zcardiovascular disease from cumulative cigarette use and the impact of smoking intensity Epidemiol. 2016 May; 27(3): 395-404.

11. Engström G, Hedblad B, Eriksson KF, Janzonm L, Lindgärde F. Complement C3 is a risk factor for the development of diabetes: a population-based cohort study. Diabetes. 2005 Feb; 54(2): 570-575.

12. Woodell A, Jones BW, Williamson T, Schnabolk G, Tomlinson S, Atkinson C, and Rohrer A Targeted Inhibitor of the Alternative Complement Pathway Accelerates Recovery From Smoke-Induced Ocular Injury. Invest Ophthalmol Vis Sci. 2016 Apr; 57(4): 1728-1737.

13. Firpo A, Polley MJ, Becker CG. The effect of tobacco derived products on the human complement system. Immunobiol. 1983. 164:318-25. 
14. Merle NS, Noe R, Halbwachs-Mecarelli L, Bacchi VF and Roumenina Complement system part II: role in immunity. Front. Immunol., 26 May 2015 | https://doi.org/10.3389/fimmu.2015.00257

15. Rich R, Fleisher T, Shearer W, Schroeder H, Frew A, Weyand C. Clinical Immunology. 5th Edition. Elsevier. Published:13th March 2018.

16. Costabile M. Measuring the 50\% haemolytic complement (CH50) activity of serum. J Vis Exp. 2010 Mar 29;(37).

17. Mahrukh S and Nageen H. (Levels of inflammatory markers (complement C3, Complement C4 and Creactive protein) in smokers. African Journal of Biotechnology , 201119 December ; 10(82), 1921119217

18. Janatova J, and Tack Fourth component of human complement: studies of an amine-sensitive site comprised of a thiol component. Biochemist, 1981; 20 (9), 2394-2402.

19. Sullivan KE and Winkelstein JA, Chapter 21: "Deficiencies of the Complement System." Editors Stiehm, ER, Ochs, HD Winkelstein, JA. Immunologic Disorders in Infants \& Children 5th Edition. Elsevier. Philadephia, 2004; pages 652-683.

20. Liszewski, MK, Atkinson, JP. Inherited disorders of the complement system. Uptodate, August 2014. UpToDate Terms of Use. (C2019 UpToDate, Inc. Available from: https://www.uptodate.com/contents/inherited-disorders-of-the-complement-system

21. Giuca MR, Pasini M, Tecco S, Giuca G, Marzo G. Levels of salivary immunoglobulins and periodontal evaluation in smoking patients. BMC Immunol.2014 Feb 6;15:5. doi: 10.1186/1471-2172-15-5.

22. Alper CA, and Rosen FS. Clinical applications of complement assays. Adv Intern Med; 1975 20:6188.

23. Alexandrov LB;Ju YS; Haase K.Mutational Signatures associated with Tobacco Smoking in Human Cancer .Sci.04 Nov.2016;354(6312):618-622.

24. Pessione F, Ramond MJ, Njapoum C, Duchatellem V, Degott C, Erlinger S .et al. Cigarette smoking and hepatic lesions in patients with chronic hepatitis C. Hepatology. 2001; 34:121-25.

25. Husain K, Scott BR, Reddy SK, Somani SM. Chronic ethanol and nicotine interaction on rat tissue antioxidant defense system. 2001 Oct;25(2):89-97.

26. Tarbiah, N. Investigation the effects of cigarette smoke on immunoglobulin levels in serum and saliva samples of smoker and non-Smoker subjects using antibody-microarray technology. PhD thesis, University of Nottingham.(2017); This article is made available under the University of Nottingham End User licence and may be reused according to the conditions of the licence. For more details see: http://eprints.nottingham.ac.uk/end_user_agreement.pdf .

27. Wang B, Zhang Y, Xu D Z, Wang AH, Zhang L, Sun CS, et al. [Meta-analysis on the relationship between tobacco smoking, alcohol drinking and p53 alteration in cases with esophageal carcinoma]. Zhonghua Liuxingbingxue Zazhi . 2004;25(9):775-778.

28. Kew RR and Ghebrehiwet BA. Characterization of the third component of complement (C3) after activation by cigarette smoke. Clin Immunol Immunopathol. 1987; 44:248-58. 
29. Roohi $\mathrm{N}$ and Mehjabeen Effects of cigarette smoking on serum protein profile in male active and passive smokers. Punjab Univ. J. Zool. 2017; 32:209-15.

\section{Tables}

Table (1): Serum levels of C3 and C4 in heavy smokers compared with a control group.

\begin{tabular}{|c|c|c|c|c|c|c|}
\hline & Subject & No. of patients & $\begin{array}{c}\text { Mean } \pm \text { S. D. } \\
\mathrm{mg} / \mathrm{dl}\end{array}$ & $\begin{array}{l}\text { Std. error } \\
\text { Mean }\end{array}$ & $\begin{array}{c}\text { Extreme values } \\
\mathrm{mg} / \mathrm{dl}\end{array}$ & Sig. \\
\hline \multirow[t]{2}{*}{$\mathrm{C} 3$} & Smoker & 30 & $183.73 \pm 278.20$ & 71.818 & $94.2-232.9$ & 0.610 \\
\hline & Control & 30 & $146.24 \pm 41.46$ & 10.703 & $91-156$ & \\
\hline \multirow[t]{2}{*}{$\mathrm{C} 4$} & Smoker & 30 & $31.30 \pm 9.18$ & 2.371 & $13-76.2$ & 0.762 \\
\hline & Control & 30 & $29.80 \pm 16.65$ & 4.299 & $20-50$ & \\
\hline
\end{tabular}

$* \mathrm{P} \leq 0.05$

Table 2: Hemolytic complement activity with all dilutions in smokers compared with the control group.

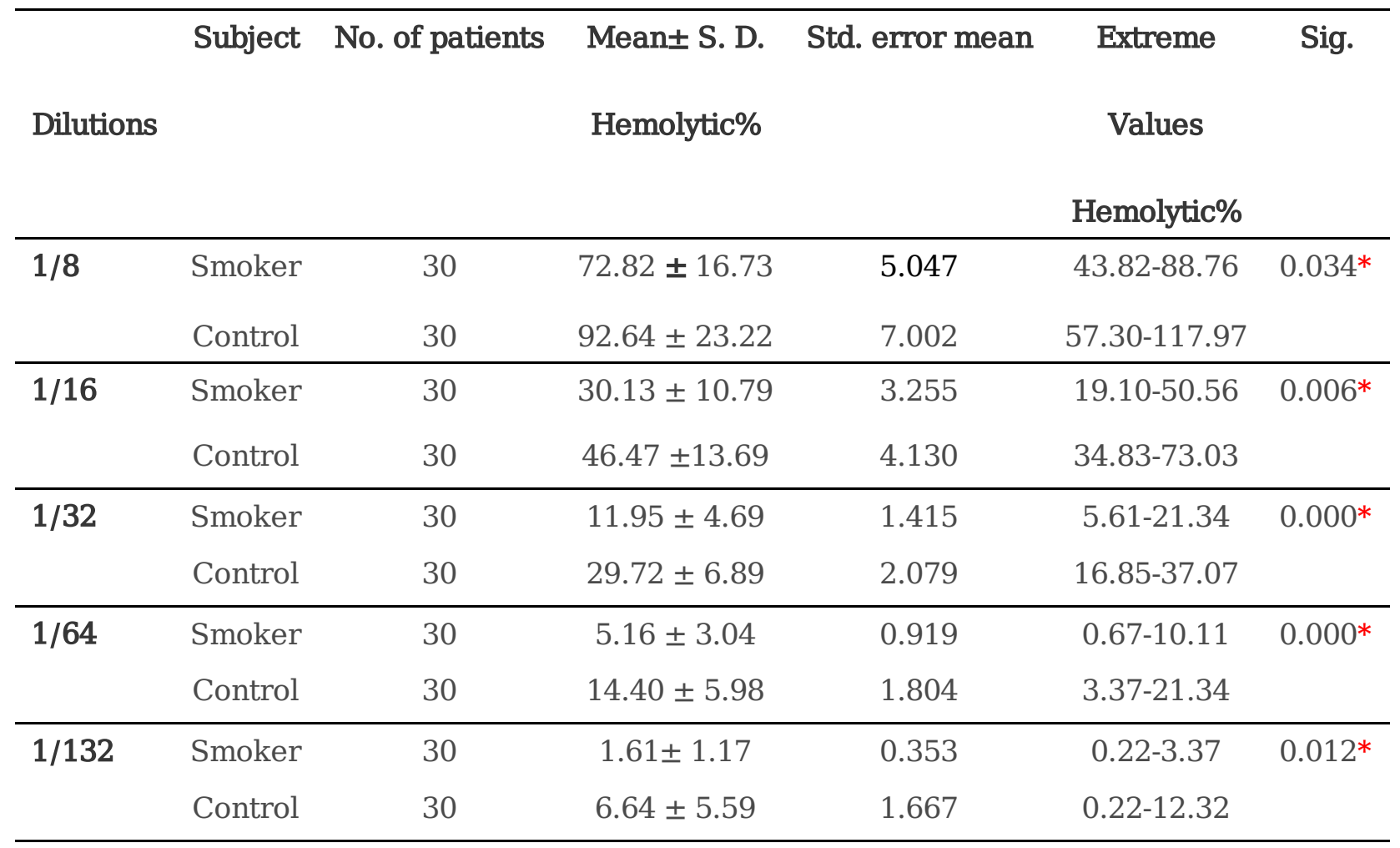

$* \mathrm{P} \leq 0.05$ 
Table 3a and b: Determining the value of hemolytic activity CH50 using an inverse equation for smokers and the control group.

\section{Control}

\begin{tabular}{|c|c|c|c|c|c|c|}
\hline \multicolumn{6}{|c|}{ Coefficients } & \multirow{3}{*}{$\begin{array}{l}\text { Equation } \\
Y=3.43+714.075 / 50 \\
Y=17.7115 \approx 18 \\
\%\end{array}$} \\
\hline & \multicolumn{2}{|c|}{$\begin{array}{c}\text { Unstandardized } \\
\text { Coefficients }\end{array}$} & \multirow{2}{*}{$\begin{array}{c}\text { Standardized } \\
\text { Coefficients } \\
\text { Beta }\end{array}$} & \multirow[t]{2}{*}{$\mathrm{T}$} & \multirow[t]{2}{*}{ Sig. } & \\
\hline & B & $\begin{array}{l}\text { Std. } \\
\text { Error }\end{array}$ & & & & \\
\hline $\begin{array}{l}1 / \\
\text { Dilutions( } \\
\text { ) }\end{array}$ & 714.075 & 29.097 & .998 & 24.542 & .000 & \\
\hline Constant( & 3.430 & 1.877 & & 1.827 & .165 & \\
\hline
\end{tabular}

\section{Smokers}

\begin{tabular}{|c|c|c|c|c|c|c|}
\hline \multicolumn{6}{|c|}{ Coefficients } & Equation \\
\hline & \multicolumn{2}{|c|}{$\begin{array}{c}\text { Unstandardized } \\
\text { Coefficients }\end{array}$} & \multirow{2}{*}{\begin{tabular}{|c|} 
Standardized Coefficients \\
Beta \\
\end{tabular}} & \multirow[t]{2}{*}{$\mathrm{T}$} & \multirow[t]{2}{*}{ Sig. } & \multirow{4}{*}{$\begin{array}{l}Y=-5.31+612.108 / 50 \\
Y=6.93 \approx 7 \%\end{array}$} \\
\hline & B & Std. Error & & & & \\
\hline 1 / Dilutions( ) & 612.108 & 26.734 & .997 & 22.896 & .000 & \\
\hline Constant( & -5.310 & 1.725 & & -3.079 & .054 & \\
\hline
\end{tabular}

\section{Figures}




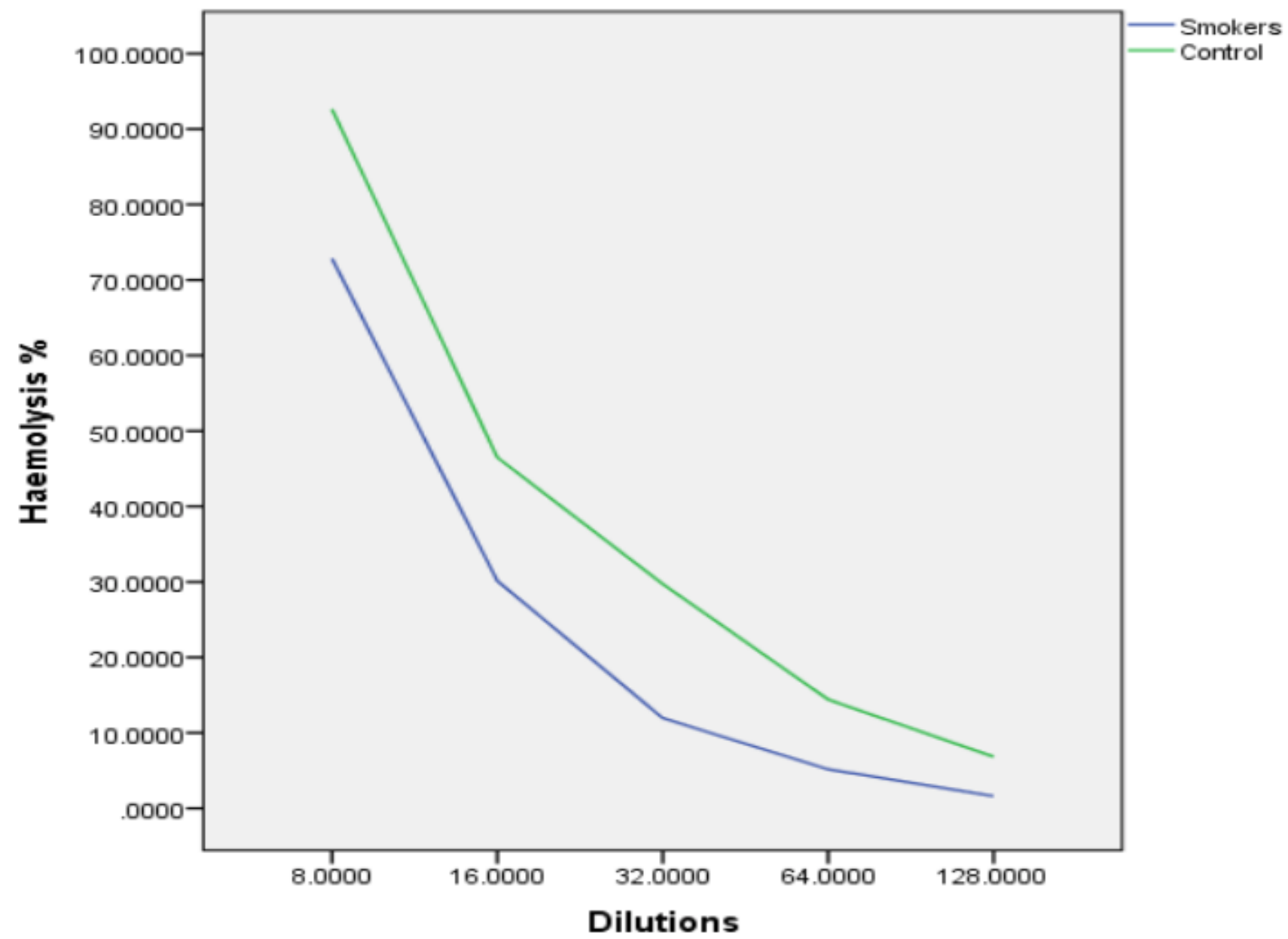

Figure 1

Hemolytic activity in smokers and the control group

\section{Supplementary Files}

This is a list of supplementary files associated with this preprint. Click to download.

- supplement1.png

- supplement1.png 